\title{
UBUNTU AND SOCIAL CAPITAL FACTORS IN FAMILY BUSINESSES
}

\section{Special Invited Essay}

\author{
Dr William P Venter, Founder and Chairman of the Altron Group \\ MBA (Wales), M Phil (Cum Laude UJ), D Phil (UJ) \\ wpventer@altron.co.za
}

\begin{abstract}
The current study is an investigation of social capital, and more particularly the support of the concept of ubuntu in large family businesses in South Africa. Insights into the social responsibility activities of some of the largest family businesses in South Africa, obtained through semi-structured interviews, clearly indicate the important role which the social responsibility ubuntu activities of these businesses play in caring for the community. As South Africa has a mainly "individualistic economic community", it is interesting to observe how the collectivistic notion of ubuntu is practised in the social responsibility activities of family business groups.
\end{abstract}

Key words and phrases: ubuntu, social responsibility, social capital, family business, conditional matrix

\section{Introduction}

Although individualism and entrepreneurship appear to be the chief modus operandi of businesses in South Africa, it is interesting to observe the collective ubuntu culture of social capital/social responsibility activities that are apparent in businesses, and family businesses in particular. Jones, Nyland and Pollitt (2001:7-8) liken the social capital activities of businesses to ubuntu. The current article investigates the prevalence of collective ubuntu social capital activities in the mainly individualistic South African business culture. The collectivistic premise of ubuntu, of "I am because we are; I can only be a person through others", is in direct contrast to Western individualism (Parr, 2006:26). It further emphasises the advantage that $u$ buntu brings about through collective collaboration of "caring, dignity and respect" (Poovan, Du Toit \& Engelbrecht, 2006:17), enabling the weaving and re-weaving of relations to foster relationships and build human dignity (Ngoenha, 2006:125,132). Ubuntu is called for in social capital activities of businesses in South Africa because of the high unemployment and significant percentage of orphaned HIV/Aids children (Maqoko \& Dreyer, 2007:717-718). Family businesses have the unique potential to promote economic growth, create new jobs and to implicitly contribute to social stability in South Africa (Venter, Boshoff \& Maas (2003:1). It is in this regard that the ubuntu concept, closely related to the social capital actions of family businesses, can play an important role in societal and economic stability. 
The communal social capital activities of successful family firms are far less frequently reported in business literature than are the social capital activities of non-family businesses (Lester \& Canella, 2006:767). The current study hopefully fills this important gap in the family business literature, which is especially important when seen in the light of a recent Fortune 500 companies report. This indicates that family-owned businesses have more community-friendly policies than non-family owned firms (Stavrou, Kassinis \& Filotheou, 2007:157). A study by Venter (2007:378) concerning the factors that play a role in the superior performance of family businesses, as well as the successful generation succession in these businesses, indicates social capital as the second most important factor in the successful functioning of family businesses.

The current study is then in some senses unique and valuable because family business owners are usually reluctant to talk about their social capital activities, as they invariably feel they do not wish to boast or seek publicity. For these reasons little is known about the true social contribution of family businesses to the social welfare of their communities. Family businesses are especially difficult to investigate because of their inclination towards privacy (Davis, 1983:55; Poutziouris, Steier \& Smyrnios, 2004:7). This has led to their well known privacy policies, as media exposure could disrupt their personal lives and bring unwanted attention to family members (Venter, 2003:10).

The investigation that follows primarily investigates the theoretical background and the prevalence of social responsibility activities in family businesses. Secondly, this article discloses a number of interviews with prominent South African family-business owners concerning the importance of social responsibility activities in their businesses.

\section{Literature review}

\section{Social capital}

\section{“A business that makes nothing but money is a poor business.” Henry Ford}

A very special relationship exists, in general, between a business and its social environment. This phenomenon of the responsibility for social capital is similarly important in the performance of family businesses. The ubuntu effect of "caring, dignity and respect" (Poovan et al., 2006:17) is generated in the social capital activities of family-controlled businesses by their being involved in and compassionately responding to their communities in a problem-solving role and shared identity (Lester \& Canella, 2006:755, 758, 762). Both internal (human resources management practices, change management policies and environmental impact, for example) and external social capital activities (integration of community, human rights and ecological issues) are evident in such businesses (Martos \& Torraleja, 2007:121).

Social capital refers to the combined social practices, networks and partnership of businesses within the social context that such businesses operate; establishing norms and generating action towards societal needs (Karakoulaki, 2002:3,5). Family businesses have over generations developed the positive reputation of characteristically supporting 
philanthropic social welfare initiatives and projects in their communities (Ward, 2003:72). The endeavour of family businesses to reinforce and support social-community concepts leads to a stronger sense of identity, which ultimately has a powerful effect on most collective business operations, thus supporting the development of a healthy society (Aronoff, Astrachan \& Ward, 1996:13; Aronoff \& Ward, 2001:31). Uhlaner, Van GoorBalk and Masurel (2004:191) refer to this form of ubuntu activity in businesses as "social entrepreneurship".

In the South African context, there are remarkable examples of family business owners with a sense of significant social responsibility, not only towards the community at large, but also within their own businesses. For example, the philanthropic nature of Sir Ernest Oppenheimer was described by the London Times as a "deeply-developed social conscience", leading to the establishment of the Ernest Oppenheimer Memorial Trust, which to this day still continues the altruistic activities he initiated (Hocking, 1973:334). Whilst still alive, the second generation chairman of Toyota SA, the late Bert Wessels, was involved in many social responsibility activities, always based on a belief in the equality of all people, regardless of race colour or creed, even during the apartheid era (Toyota Chairman Wessels dies, 2002:1-2). Former president Nelson Mandela acknowledged the active social responsibility involvement of Sol Kerzner and his late son Butch, "to give back to their country" (Sol Kerzner, 2004:2). Dick Enthoven, owner of the Spier Wine Estate, emphasises the fact that financial performance in itself is not the only measure of business success (Nevill, 2004:2). Social and environmental factors must be taken into consideration. Sir Donald Gordon, founder of the Liberty Group, was described as always being sensitive to the needs of those less fortunate than others, and was not afraid of redressing some of the disparities in society (Romain, 1989:44). Dr Bill Venter, founder and chairman of the Altron Group, refers to the company's internal and external social responsibility activities, job-creation programmes and community projects as "having a heart" for society (Koenderman, 1982:23).

The trend towards emphasis of the social responsibility activities of businesses is globally evident. Corporate social responsibility is regarded as advantageous to businesses economically, due to their involvement in ethical, legal and philanthropic issues (Uhlaner et al., 2004:192). One of India's largest family businesses, the Tata Group, regards their philanthropic involvement in their communities as more rewarding than the inspiration for making money (Ellis, 2002:63). The Bill Gates and Warren Buffett families have indicated their intention of, and are already heavily involved in, donating some of their huge family wealth to selective charities (Wood, 2004:19). The second-generation Walton family similarly supports social upliftment, especially in advancing education of the underprivileged and the American people per se (Serwer, 2004:63).

There is also, on the other hand, clear evidence that non-family businesses seem to be less involved in social responsibility activities than family businesses. A study of $\mathrm{N}=42$ Dutch family businesses brings to light a serious lack of social entrepreneurship (Uhlaner et al., 2004:191). The Anglo American Corporation reports its disappointment in the minimal support given to philanthropic social development in African countries outside of South Africa (Anglo American, 2005:16). For this reason Anglo American has made a 
commitment to identify and develop significant African and worldwide social responsibility programmes (Anglo American, 2005:16).

It is clear from the above discussion that the ubuntu-like practice by large family businesses of assuming social responsibility, and becoming an entity through others by means of collective caring, leads to dignity and respect within communities (Ngoenha, 2006:125, 132; Parr, 2006:26; Poovan et al., 2006:17).

The ubuntu role family businesses play in being involved in the social responsibility activities of their communities can best be described as general philanthropy, meaningful political involvement, environmental care, and giving consideration to culture, coupled with the advancement of sports and other social upliftment projects.

\section{Philanthropy}

Successful family businesses keenly pursue philanthropic responsibilities, often in appreciation of the contribution of communities towards the success of the company (Kleberg, 2001:1; Ward, 2003:128). In this way, the firm acknowledges the ubuntu principle of "I am because we are" (Parr, 2006:26) - in other words: this family business exists through others. The legacy of this ubuntu-like philanthropic care of the community has been preserved by the heirs of the business over decades (Wood, 2004:20), thus conserving the family members' value systems of responsible care towards the community (Lovell, 2006:3; Ward, 2003:129), and thereby gaining the community's goodwill, loyalty and trust (Kleberg, 2001:3, 7-8). Raymond Ackerman and his son, Gareth, regard philanthropic community care as "the core that binds the family in cooperation with society" (Salgado, 2006:14). It is not surprising that family foundations are known to bring about innovative philanthropic activities, for which many family businesses are famous (Kleberg, 2001:10).

This ubuntu-like philanthropic care, at all levels of society, has been practised by major South African family businesses such as Altron, Anglo American, De Beers, Rembrandt, PG Glass and the Toyota Group (Dommisse \& Esterhuyse, 2005:216, 218, 396; Hocking, 1973:306-307, 489; Lubner \& Lubner 1997:64; Rogerson, 2003:17, 21; Wessels, 1988:203). Dr Anton Rupert, of the Rembrandt Group, became involved in Lesotho, operating with a conviction that South Africa should not be oblivious to its starving and underprivileged neighbours (Anton Rupert, 2006:9; Coulson, 2006:42). Apart from many other community projects, Lubners support Street-Wise, a rehabilitation project of thousands of street children towards a productive life (Lubner \& Lubner, 1997:65). Christo Wiese of Pep Stores went about creating a clothing company that made a major contribution to the South African economy in providing clothing affordable to underprivileged people, and in some measure endow these people with dignity (Herd, 2006:53). The founder of Macsteel, Eric Samson, believes that the more you serve your community, the more you receive from it (Formby, 2006:27). Early exposure of family members to strategic philanthropic decisions serves as a good training ground for aspiring future family business leadership (LaSpada, 2006:3, 5). 
The contribution of family business founders toward training and education is seen in the following examples: The founder of Stuttafords department store and Cape Gates, Samson Stuttaford, largely established the library at the University of Cape Town (University of Cape Town, 2006:1). Dr Mendel Kaplan, founder of Sharon Steel, has generously contributed to several universities in South Africa and abroad (University of Cape Town, 2006:1). The Venter family financially supported the refurbishing of the Bram Fischer Library and the Legal Resources Centre, Elizabeth House, Johannesburg (Rogerson, 2003:92). The founder of the Altron Group, Dr Bill Venter, personally funded eight schools as well as many computer centres for previously disadvantaged children, where some 8000 children are currently educated (Altron Code of Conduct, 2006:2; Rogerson, 2003:171). These were established in rural areas such as Elliotdale, Qunu and Nkalane in the Eastern Province, and Ulundi in Kwazulu-Natal. Dr Bill Venter has personally funded many bursaries to universities for disadvantaged students.

The Walton family of Wall-Mart in the USA concentrate their philanthropic donations mainly on advancing a variety of educational endeavours (Serwer, 2004:57-58). Pick 'n Pay's Dr Raymond Ackerman and his wife Wendy's care for education of underprivileged young people stretches far back to their involvement in night schools in Cape Town in their younger days, a passion that they still pursue in the well-documented support of their education and literacy programmes (Prichard, 2004:47, 318; Prichard, 2005:154, 168). They believe that education will secure a satisfying future for the recipients of their largesse (Prichard, 2004:47, 318; Prichard, 2005:154, 168). Education of previously disadvantaged persons is financially supported by the Dr Albert Wessels Trust, the Altron Bill Venter family-business trust, and various Rembrandt Foundations throughout South Africa (Altron Code of Conduct, 2006:1; Doolan, 2005:22; Rogerson, 2003:85; Vision was in advance of the new SA, 2001:2). It was Dr Albert Wessels' personal aspiration to train unskilled, often illiterate individuals to become competent Toyota factory workers (Von Ahlefeldt, 1983:8). The support Liberty Life has received from its insurance policy holders was acknowledged by its generous donation of over R30 million towards the establishment of the Gordon Institute of Business Science (GIBS) (About Donald Gordon, 2006:1). GIBS was named after Sir Donald Gordon, founder and former chairman of Liberty Life, in view of his acknowledgement and support of education as a critical component of business and the development of the country.

The support of family businesses towards the development of entrepreneurial programmes is also evident. Anglo American empowers and supports the development of various small and medium-sized enterprises as catalysts in the creation of wealth (Anglo American, 2005:14-15). During 1999 alone, the Altron Group financially supported more than 2000 SMMEs, contributing to the creation of more than 6000 jobs nationwide (Rogerson, 2003:139-143). The Donald Gordon Foundation largely funds the manufacturing plant of Freeplay Radio, securing jobs for 250 disabled individuals in the production of a few thousand wind-up, electricity-free radios per month (Baylis, 2006:1; Clockwork radios, 2002:1; Dahle, 1999:170). The Rupert family of the Rembrandt Group has instituted the Small Business Development Corporation (SBDC) and the Lesotho Development Corporation in order to encourage and stimulate the development of 
entrepreneurship in South Africa and Lesotho, creating almost a million jobs (Barron, 2006:15, Dommisse \& Esterhuyse, 2005:241; 384-389; Doolan, 2005:22).

The contribution of family businesses towards health is also apparent. The Chairman of De Beers, Nicky Oppenheimer, personally plays a major role in HIV/Aids management in South Africa (De Beers, 2005:16-25), as does the Watson family (Binedell, 2005:7). Rembrandt's Dr Anton Rupert funded urgent medical care for over forty years by flying doctors to Lesotho for medical emergency situations (Barron, 2006:15; Dommisse, 2006:17). Microsoft's Bill and Melinda Gates are significantly involved in the treatment of measles, malaria and Aids in Africa - practising the motto that other individuals' lives are just as important as their own (White, 2006:45-49). Moreover, the Donald Gordon Foundation funded the Wits University Donald Gordon Medical Centre (WDGMC) in Pinetown, Johannesburg (WDGMC, 2008).

\section{Political influence}

Indications are that family businesses show resilience during times of political instability (Aronoff \& Ward, 1995:122; Gibson, 2002:128; Heck, Upton, Bellet, Dunn \& Parady, 1994:3-4). Venter (2003:22) indicates that the main family-business groups in South Africa have performed with dedication and distinction during turbulent and volatile times. There seems to be a special form of resilience shown by family businesses during difficult times; this could be the result of subtle political involvement of family businesses during these times which contributes to positive reform, as well as high morale in the companies they control.

The delicate political involvement of family-business members is evident in South Africa's history. The founder of De Beers, Sir Ernest Oppenheimer, and his wife Ina personally funded the treatment of over 200 soldiers needing plastic surgery, treated at Brenthurst, which was made available as a military hospital during the Second World War (Hocking, 1973:193, 195). Sir Ernest Oppenheimer actively practised the policy attributed to Cecil Rhodes, advocating a policy of "equal rights for all civilised men" (Hocking, 1973:102, 132). Sir Ernest's policy was similarly advocated by Harry Oppenheimer in securing the prosperity of the millions of Africans in South Africa, inevitably leading to frequent crossing of swords with Dr Hendrik Verwoerd, former Prime Minister of South Africa (Hocking, 1973:306-307).

Toyota South Africa's Dr Albert Wessels strove to eliminate any form of racial or language discrimination at the company (Vision was in advance of the new SA, 2001:1; Wessels, 1988:212). Dr Wessels established the Albert Wessels Trust in 1972, encouraging black South Africans to gain political, intellectual and economic equity through education (Vision was in advance of the new SA, 2001:2). Through the Toyota SA Foundation, the Toyota Technical Education Programme, and the Toyota SA Social Development Committee, those previously disadvantaged are still actively supported. Dr Bill Venter of Altron applied the principle of preserving the human dignity of all individuals working in the company, declaring that "every quarter of our multi-ethnic society will have to contribute its share of talent to the national demand if we are to cope 
with the socio-economic rigours of the twenty-first century", as the South African political architecture was regarded as woefully inadequate to cater for the country's future demands (Venter, 1984:6). Dr Bill Venter instituted a fundamental policy of nondiscrimination with regard to race and gender, and promotion on merit, as the fundamental philosophy of the Altron Group as far back as 1980 (Rogerson, 2003:35-36, 66). Dr Venter pioneered racially integrated gymnasiums, canteens and comfort facilities at Standard Telephones and Cables (STC) in Boksburg in the early 1980s (Rogerson, 2003:35-36).

Dr Raymond Ackerman made sterling efforts to eradicate apartheid policies by, for instance, appointing, against the government's Group Areas Act policy, Pick 'n Pay's first black manager in a Rondebosch store (Prichard, 2004:39, 90-92, 153). At the same time Dr Ackerman established South Africa's first multicultural golf club at Clovelly, Cape Town (Prichard, 2004:161-163).

Dr Anton Rupert constantly prophesied the co-existence and partnership of different groups in South Africa (Dommisse \& Esterhuyse, 2005:12), openly criticising the apartheid government locally and abroad, in a constructive manner, without leading to awkward confrontations (Doolan, 2005:22). Dr Rupert showed his constant support for South Africa; when it was obvious that it would be more comfortable to use Geneva as his business headquarters, he took the responsibility of remaining in South Africa, so that he would be able to be more involved in the reform process (Dommisse \& Esterhuyse, 2005:214). In his commitment to reform, Dr Rupert initiated the establishment of the Development Bank for Equatorial and Southern Africa (Edesa) to provide development capital to private enterprise in southern Africa (Dommisse \& Esterhuyse, 2005:214).

Constructive political involvement was shown by Dr Rupert and Harry Oppenheimer after the horrendous Soweto violence of 16 June, 1976, by organising a meeting with Dr. Nthatho Motlana as chair (Dommisse \& Esterhuyse, 2005:237-239). The meeting, held in Johannesburg on 29 November, 1976, had the objective of discussing and reaching conclusions about alleviating the abject misery, poverty and non-existent political rights of black South Africans (Dommisse \& Esterhuyse, 2005:237-239). A consequence of this meeting was the establishment, in 1977, of the Urban Development Foundation, with a mandate to improve the quality of life of black South Africans, including black leaders (Prichard, 2004:146; Prichard, 2005:82). Significantly, Dr Raymond Ackerman was a member of the committee formed to implement the mandate (Prichard, 2004:146; Prichard, 2005:82). Dr Albert Wessels simultaneously established a small-business development unit, namely the Toyota Urban Conservancy Project, to encourage black empowerment (Vision was in advance of the new SA, 2001:2).

The Altech Group, under the auspices of Dr Bill Venter, issued a staff notice to 6000 employees on 9 April, 1979, informing personnel of the Altech Group's commitment then to improve the working conditions of all their employees, irrespective of race, religion or colour (Rogerson, 2003:17). This staff notice, against prevailing prohibitive legislation, terminated any segregation of eating, comfort and work facilities among employees in the Altech Group, as well as guaranteeing equal employment practices, 
leading to equal pay for all for equal work and an increase of the appointment of blacks and other non-whites in management and supervisory positions (Rogerson, 2003:21). During April 1979, Dr Bill Venter announced a training scheme for black engineers at ITT factories in Belgium (Rogerson, 2003:17). This was the first step of its kind ever undertaken by the electronics industry in South Africa.

The Spier Vineyard Trust, under the leadership of the Enthoven family, has been proactive in land reform: it has provided funds for building of homes, offered employees a 25 percent share in the 60ha of vineyards, and supported the development of 12 independent organic farmers on the Spier property (Van Wyk, 2003:4; Nevill, 2004:2).

\section{Aim}

The aim of the current study was to investigate the social capital activities of some of the most prominent family business groups in South Africa.

\section{Research method}

The current study was a qualitative, exploratory investigation to determine the frequency of different forms of social capital, inter alia ubuntu activities, in some of the most prominent family businesses in South Africa by means of open-ended and closed-ended face-to-face interviews (Cooper \& Schindler, 2006:141, 143). A quantitative, deductive approach was followed, with a detailed identification of distinct variables with standardised measurements and analyses of statistics (Neuman, 2000:122-123). The data were finally quantified through statistical analysis (Malhotra, 1996:164). The enquiry into the phenomenon of social capital activities in family businesses in South Africa is, to the best of the researcher's knowledge, a landmark and unique investigation. For this reason an exploratory, qualitative enquiry was proposed. Different authors support the qualitative method of investigation, especially to explain an interpretive framework of the unfolding process of a social phenomenon (Babbie, 2005:387; Bornheim, 2000:164; Van Maanen, 1979:520).

\section{Participants/Sample}

Due to the qualitative investigation of the current study, a non-probability or non-random sampling method was used (Kerlinger \& Lee, 2000:179; Malhotra, 1996:357-417; Neuman, 2000:196). In the case of non-probability, non-random sampling, the sample size is not representative of the population, but rather representative of the social phenomenon under investigation (Neuman, 2000:196). In the case of the current qualitative study, a purposive non-random sample was selected that specifically consisted of family members actively involved in family-business groups in South Africa. Five of the largest, most prominent family business owners in South Africa, acting as CEOs in their companies, participated in the survey. The participants were all male, with ages varying between 43 and 75 . The participating family business members were in their second- to third-generation succession of their companies, having had ownership of the companies for between 30 and 117 years. The family businesses were involved in, inter 
alia, mining, retail, property, manufacturing, wholesale, banking, food processing, and wine production.

\section{Measuring instruments}

The research was a grounded investigation, carried out by means of standardised, semistructured, one-on-one interviews, documenting perceived experiences of individuals either involved in or employed by family businesses. The personal interview is considered to be the most powerful tool and most practical method of investigation for obtaining information on the beliefs, actions and intentions of individuals (Kerlinger \& Lee, 2000:601). The standardised interview is regarded as being based on subjective narratives representing the reality of the interviewee (Henning, Van Rensburg \& Smit, 2005:55). The essence of the experiences of these individuals was formulated, discussed and interpreted by means of triangulation against the reported literature.

Multiple, semi-structured, individual interviews, with open-ended as well as closed-end questions, were conducted in order to investigate the functional success or failure of "familiness" in different South African family-business groups. The interview is generally regarded as a powerful method of investigation, revealing data about attitudes, intentions, feelings and behaviours which no other research tool is quite capable of accommodating (Kerlinger \& Lee, 2000:699). The cost, time, effort and considerable skill needed for interviewing (Greef, 2005:297; Kerlinger \& Lee, 2000:699) made it both difficult and impossible to investigate a large sample size.

Interviews were scheduled with different family representatives in managerial positions in family-business groups in South Africa. The respondents were informed about the subject under investigation. Questions concerning the social capital activities in the family businesses were related to their past, present and future orientations (Kerlinger \& Lee, 2000:602). The open-ended questions were constructed, as recommended by Henning et al. (2005:158-159), with initial introductory questions, followed by intermediate and concluding questions. The interviews were evaluated, coded and categorised by means of a Microsoft Excel worksheet, using standard content-analysis techniques (Lincoln \& Guba, 1985:337-338) and then loaded onto the Excel Word computer software. The data classification by means of computer software provides for the assignment of the themes into categories, called coding (Henning et al., 2005:129) or enumeration of frequencies (Lincoln \& Guba, 1985:338). The initial coding and enumeration were undertaken by the author and audited by two individuals with doctoral degrees. Any possible discrepancies that existed were resolved by these three individuals through discussion. This process enabled the researcher to observe the different patterns within categories in terms of their similarities and variations (Henning et al., 2005:129). Finally, connections between the different categories were formed. Data triangulation took place in the discussion of the findings, using information from the interviews, archival material and literature reviews (De Vos, 2005:362). Therefore, variables that emerged from the literature review were compared with the variables that emerged from the case studies through interviewing (Barringer, Jones, \& Neubaum, 2005:678). The 
discussion incorporated the four constant, comparative stages of evaluation according to grounded theory, as suggested by Glaser and Strauss (1967:105-113).

\section{Problem statement and research questions}

The main problem investigated in the current study was to explore the existence or nonexistence of social capital in family-business groups in South Africa, and the role it plays in generation-transition of family businesses. The following research questions were asked:

Question 1: How does the family-business performance relate to the firm's social capital activities?

Question 2: Would you say that social capital leads to the superior performance of family businesses when they are compared with non-family businesses?

Question 3: What is the role of social capital in the family business?

\section{Results}

The results are discussed in relationship to each research question.

Question 1: How does the family-business performance relate to the firm's social capital activities?

The relationship between family-business performance and social capital activities of family businesses is reported in Table 1 and Figure 1.

Table 1: The relationship between family-business performance and social capital activities of family businesses

\begin{tabular}{|l|c|c|l|}
\hline Code & 5 & 1 & $\begin{array}{l}\text { There are two parts to philanthropy: there is charity, which is helping those } \\
\text { who can't help themselves; and social investment, which is helping people } \\
\text { who can help themselves, but who do not have the experience or the } \\
\text { resources (financial, or otherwise) to make these happen. }\end{array}$ \\
\hline Philanthropy & $\begin{array}{l}\text { Even the grandchildren are exposed to social responsibility issues from the } \\
\text { age of 16, when they receive their own allowances and have to report to } \\
\text { the family business council on the monies spent. }\end{array}$ \\
\hline 3 & $\begin{array}{l}\text { You know, there are 270 offices, it is about close on 3000 people, and } \\
\text { there is a strong sense of community, social involvement. So we push very } \\
\text { hard on each of those offices around the country to be involved in } \\
\text { philanthropy. }\end{array}$ \\
\hline 4 & $\begin{array}{l}\text { During the days of petrol restrictions, my father took me to drive with him, } \\
\text { taxiing people to Nkandla, Jacob Zuma's home town, but we could not } \\
\text { come back, it was a long weekend, there was not petrol and I spent that } \\
\text { entire weekend in a little village, no ablutions, there is nothing, and if you } \\
\text { look at the food that has been cooked, and the water.... }\end{array}$ \\
\hline
\end{tabular}


Table 1 continued

\begin{tabular}{|c|c|c|c|}
\hline Code & : & : & Example \\
\hline & & 5 & $\begin{array}{l}\text { [Name of family business's] whole existence is about philanthropy. You } \\
\text { will know this Dr Venter, because you and I are from the same vintage, } \\
\text { that when I grew up in Upington, when you saw a child of colour in decent } \\
\text { clothes, that was an exception. [Family business name] made the } \\
\text { difference. In } 1966 \text { you could dress a child in our family store from head to } \\
\text { toe for under a rand. }\end{array}$ \\
\hline \multirow[t]{3}{*}{ Instilled values } & 3 & 1 & $\begin{array}{l}\text { My father agreed with us as a family, about what the family was going to } \\
\text { give to philanthropy and how much we as children should give. He wanted } \\
\text { us to feel that we would recognise these charities and that it wasn't just his } \\
\text { idea. So he infiltrated into us a type of, I would not call it a discipline, but } \\
\text { a type of attitude that said there is a time to make money, there is a time to } \\
\text { look after our own interests and there is a time to look after the interests of } \\
\text { others. So that was the kind of culture and philosophy that he and my } \\
\text { mother together brought into the family. }\end{array}$ \\
\hline & & 2 & $\begin{array}{l}\text { I was reflecting the other day, on the number of children who came to live } \\
\text { with our family, from other families, because my father was a school } \\
\text { principal as well as running the family business, he was trying to help out } \\
\text { with these families, educating these children. }\end{array}$ \\
\hline & & 3 & $\begin{array}{l}\text { I think it was just a feeling that if you were successful, you were } \\
\text { privileged, and then you could not just sort of, you know, I think it is an } \\
\text { important element of the family to sort of not be like Scrooge, go and } \\
\text { count your money every evening and see how much money you have got. } \\
\text { If you have got enough, then that is fine, then you must do other things for } \\
\text { other people. }\end{array}$ \\
\hline \multirow[t]{2}{*}{ Morale } & 2 & 1 & $\begin{array}{l}\text { My father had two secretaries. The one's job was a normal secretary's job. } \\
\text { The other one was a woman of character... She had the hugest heart. Her } \\
\text { job was to do two things, one, everyone in the organisation had a } \\
\text { responsibility to let her know if somebody was ill, or if there was a } \\
\text { marriage, or if there was a death. My father would respond personally and } \\
\text { people could not believe that he knew and cared for their well being. }\end{array}$ \\
\hline & & 2 & $\begin{array}{l}\text { The third leg of the table (social responsibility leg) becomes the sort of } \\
\text { driving leg, keeping the morale or the interests in the company that you } \\
\text { asked me about, because it involves all the staff. They all contribute to the } \\
\text { social and environmental issues. }\end{array}$ \\
\hline \multirow[t]{2}{*}{$\begin{array}{l}\text { Creating } \\
\text { entrepreneurs }\end{array}$} & \multirow[t]{2}{*}{2} & 1 & $\begin{array}{l}\text { Franchising has been good for us. Besides the feeling of sharing, we are } \\
\text { creating entrepreneurs. }\end{array}$ \\
\hline & & 2 & Franchising creates opportunities for entrepreneurs. \\
\hline \multirow[t]{2}{*}{$\begin{array}{l}\text { Founder sets the } \\
\text { tone }\end{array}$} & \multirow[t]{2}{*}{2} & 1 & $\begin{array}{l}\text { I think we learned from example. My father would walk into a factory and } \\
\text { ask: 'How is your wife? She wasn't well the last time I saw you?'. We saw } \\
\text { the humanity in this. That humanity went right through the business. We } \\
\text { could see clearly the response to my father's caring attitude. }\end{array}$ \\
\hline & & 2 & $\begin{array}{l}\text { I can think of hundreds of occasions where we've probably made } \\
\text { questionable business decisions, but the right human decision. Employees } \\
\text { know that unless it is beyond our control, we would not err on the side of } \\
\text { familiness, i.e. look after them, in whatever way we can, against running a } \\
\text { corporation. }\end{array}$ \\
\hline
\end{tabular}


Table 1 continued

\begin{tabular}{|l|l|l|l|}
\hline $\begin{array}{l}\text { Example of } \\
\text { parents }\end{array}$ & 2 & 1 & $\begin{array}{l}\text { My mother used to spend her entire day on a number of various causes, } \\
\text { with emphasis on three main ones. One was the development of a home for } \\
\text { retarded people - children and adults who could not find a place in society. } \\
\text { Requiring an institution, she was particularly involved in the [name of } \\
\text { orphanage], which received many, many children from families who were } \\
\text { destroyed by the Nazis during the holocaust. She also managed the } \\
\text { women's benevolent society, for persons who fall on hard times, illness, } \\
\text { were out of a job, whatever the circumstances, raising funds, and giving } \\
\text { out food, or clothing or free medical attention. My father was supportive of } \\
\text { all my mother's activities. }\end{array}$ \\
\cline { 2 - 5 } & 2 & $\begin{array}{l}\text { We had a definite view about our social responsibilities. My grandfather, } \\
\text { who was a wonderful old man, always used to say that it was easier to give } \\
\text { than to receive and that it was a responsibility. If you did well, you should } \\
\text { see to it that other people also did well. }\end{array}$ \\
\hline $\begin{array}{l}\text { Importance of } \\
\text { providing jobs }\end{array}$ & 1 & $\begin{array}{l}\text { You know, black families are upwards of 8 people. So indirectly [name of } \\
\text { family business], with that number of employees, supports the livelihood } \\
\text { and the fortunes of 50 000 x 8 individuals, that is 400 000. }\end{array}$ \\
\hline $\begin{array}{l}\text { Appointment of } \\
\text { underprivileged } \\
\text { individuals }\end{array}$ & 1 & $\begin{array}{l}\text { We often employed people with a background from an orphanage } \\
\text { upbringing. These people were introduced to the company and in 70\% of } \\
\text { cases turned out to be outstanding people. My father argued that when a } \\
\text { person came from institution with no parents, then given the opportunity to } \\
\text { develop, he would only be delighted to take it and often worked harder to } \\
\text { achieve it. }\end{array}$ \\
\hline
\end{tabular}

Figure 1: The relationship between family-business performance and social capital activities of family businesses

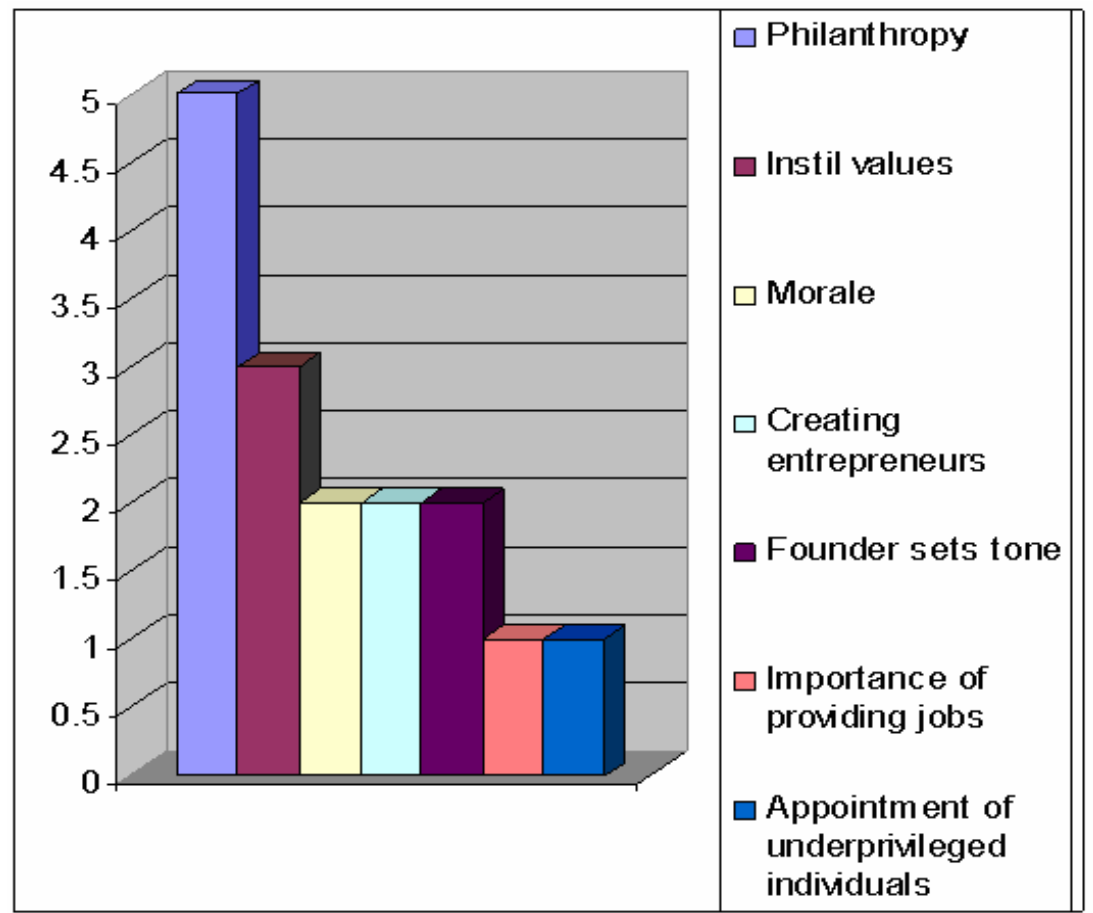


The family-business groups' activities of social responsibility are an extension of their economic performance, acknowledging the communities in which they operate. For this reason they are active in philanthropic activities $(n=5)$, instilling the values $(n=3)$ of the family business in their stakeholders, and uplifting the morale $(\mathrm{n}=2)$ of the staff. Family businesses play a major role in creating entrepreneurs $(n=2)$ outside the family business through training, education and franchising. The founder often sets the tone $(\mathrm{n}=2)$ in a family business in respect of philanthropic participation by the company as well as the family itself. An important statement made in respect of providing jobs $(\mathrm{n}=1)$ indicated that, for each individual it employed, the family business indirectly provided support for seven to ten people, since that was in general the number of dependants relying on each employee for a livelihood. In addition, training and education are offered to underprivileged individuals $(\mathrm{n}=1)$, in the belief that they are more often than not dedicated workers.

Question 2: Would you say that social capital leads to the superior performance of family businesses when they are compared with non-family businesses?

The characteristics that play an important role in the superior performance of family businesses through social capital are represented in both Table 2 and Figure 2.

Table 2: The relationship between social capital and the superior performance of family businesses

\begin{tabular}{|c|c|c|c|}
\hline Code & 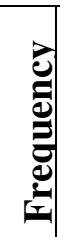 & 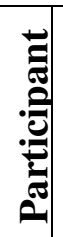 & Example \\
\hline Word of mouth & 1 & & $\begin{array}{l}\text { When Mr Mandela was released from jail, he communicated with many } \\
\text { executives and he visited many businesses. He said to me, "you know you } \\
\text { don't publicise enough what you do". I said, "you know, it is a strange } \\
\text { thing, people get to know what I do in the community". He said, "I didn't } \\
\text { know that you and your wife held bursary schemes, you should be } \\
\text { publicising that" I said, "well we just do it our way and it seemed to have } \\
\text { worked. You must realise that many people, especially prominent one's, } \\
\text { abhor publicity". }\end{array}$ \\
\hline $\begin{array}{l}\text { Appointment of } \\
\text { underprivileged } \\
\text { individuals }\end{array}$ & 1 & & $\begin{array}{l}\text { We often employed people with a background from an underprivileged } \\
\text { past and/or orphanage upbringing. These people were introduced or } \\
\text { recruited through personal visits, and in over } 70 \text { percent of cases proved } \\
\text { highly reliable. My father argued that when a person emerged from } \\
\text { institution as an orphan, then given the opportunity to develop, he would } \\
\text { not only be highly delighted but would tend to work harder and be more } \\
\text { diligent than people who were of a privileged background. }\end{array}$ \\
\hline $\begin{array}{l}\text { Providing for } \\
\text { the } \\
\text { underprivileged }\end{array}$ & 1 & & $\begin{array}{l}\text { The founder applied low cost clothing to a sector of the community that } \\
\text { really was in need. So he satisfied the need. }\end{array}$ \\
\hline $\begin{array}{l}\text { Ploughing back } \\
\text { into society }\end{array}$ & 1 & & $\begin{array}{l}\text { I think if you are successful, you can't take your money away with you. } \\
\text { You have got to pay back to society the benefits society has given you. }\end{array}$ \\
\hline
\end{tabular}


Figure 2: Characteristics that play a role in social capital leading to the superior performance of family businesses

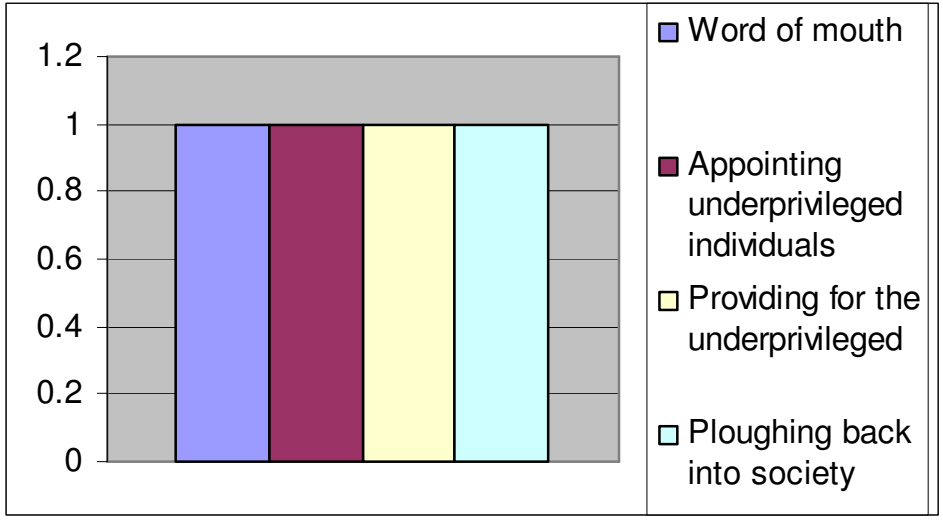

The view was generally expressed that philanthropic activities undertaken by a family business did not require wide publicity, since the deeds would be communicated by word of mouth $(\mathrm{n}=1)$, via the employees and other stakeholders. However, a conflicting opinion existed, making the point that any major philanthropic act by a business, if reported in the correct context by the press, and given a prominent profile, could inspire others to follow suit and simultaneously could increase morale within the company. The point was raised that the appointment of underprivileged individuals $(\mathrm{n}=1)$ had proved to provide outstanding workers, since such individuals appreciate the opportunity to gain the necessary experience and the opportunity to climb up the corporate ladder into more responsible jobs and to achieve better living standards. Without these job opportunities, such underprivileged employees would remain just "numbers" on the payroll. Some family businesses have a serious commitment to providing support for the underprivileged, and through philanthropy ploughing back into society $(\mathrm{n}=1)$, in this way acknowledging both the support and benefits that society has made available to the family business.

\section{Question 3: What is the role of social capital in the family business?}

The role of "familiness" in the performance of social capital is reported in Table 3 and Figure 3. 
Table 3: The role of social capital in the family business

\begin{tabular}{|c|c|c|c|}
\hline Code & : & : & Example \\
\hline \multirow[t]{3}{*}{$\begin{array}{l}\text { Priority of } \\
\text { social values }\end{array}$} & 3 & 1 & $\begin{array}{l}\text { Our social priorities started with my mother. She used to spend her } \\
\text { entire day on a number of causes, but three main ones. One was the } \\
\text { development of a home for retarded people, not only children, but } \\
\text { also adults, who could not find a place in society, and who needed } \\
\text { an institution, where they could be properly cared for and treated. } \\
\text { At the same time, exposure to others seemed to be somewhat } \\
\text { therapeutic for them. She was particularly active, (just before and } \\
\text { during world war 2, in an orphanage, took in many children from } \\
\text { families who were virtually destroyed by the Nazis during the } \\
\text { Holocaust. She was head of what was called the "Homeless-after- } \\
\text { care Programme", that continued until the children left the } \\
\text { orphanage and returned to society. If they got married, she had a } \\
\text { whole arrange; she used to go and collect wedding dresses from all } \\
\text { over and had a whole wardrobe, in different shapes and sizes, } \\
\text { colours, and so on. She would build a trousseau up for the girls } \\
\text { from the orphanage. And as we put in the book, also many of the } \\
\text { kids who matriculated, and either went to university or did not go to } \\
\text { university, she used to stream them into the companies, many } \\
\text { different companies. Nobody could ever refuse my mother's } \\
\text { request to give an orphan a job, never! She also ran the women's } \\
\text { benevolent society. }\end{array}$ \\
\hline & & 2 & $\begin{array}{l}\text { At executive meetings we always deal with the social issues - the } \\
\text { question is always asked: what are we doing on social } \\
\text { responsibility? }\end{array}$ \\
\hline & & 3 & $\begin{array}{l}\text { In South Africa we certainly were very aware of what we needed to } \\
\text { do and to participate in things like the Small Business Development } \\
\text { Corporation, to be giving funding to religious organisations, and to } \\
\text { help educate young people who could not afford it. Therefore it was } \\
\text { unquestionably one of our responsibilities and I practised that same } \\
\text { sort of philosophy. }\end{array}$ \\
\hline \multirow[t]{3}{*}{$\begin{array}{l}\text { Ploughing back } \\
\text { into the } \\
\text { community }\end{array}$} & \multirow[t]{3}{*}{3} & 1 & $\begin{array}{l}\text { Even during the apartheid years, my father was supportive of black } \\
\text { social development. He agreed with us as a family about what we } \\
\text { would give to black social development and how much we as } \\
\text { children should give. He wanted us to feel that we would also } \\
\text { recognise these charities and that it wasn't just his idea. }\end{array}$ \\
\hline & & 2 & $\begin{array}{l}\text { We are constantly looking at needs in the community that the } \\
\text { family business can attend to. }\end{array}$ \\
\hline & & 3 & $\begin{array}{l}\text { I think there is very much a sense of contribution and wanting to } \\
\text { give something back to society and it is something that from a } \\
\text { corporate culture perspective we push all the time. And I think it is } \\
\text { very part of the South African ethos these days, and it is important. }\end{array}$ \\
\hline
\end{tabular}


Table 3 continued

\begin{tabular}{|c|c|c|c|}
\hline Code & 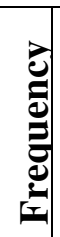 & 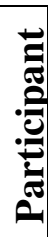 & Example \\
\hline $\begin{array}{l}\text { Political } \\
\text { influence }\end{array}$ & 3 & 1 & $\begin{array}{l}\text { Even during the apartheid years, my father was supportive of } \\
\text { people of colour. During the apartheid years we made contact with } \\
\text { the banned organisation, the ANC. There were two motives, one: to } \\
\text { really find out what their ideology would be if they were really in } \\
\text { control. We all read the freedom charter, but slogans are one thing } \\
\text { and actions are another. We tried to make them realise that } \\
\text { capitalism and apartheid were not one and the same thing. A third } \\
\text { obvious element was that we would like to see apartheid dissolved, } \\
\text { but in our time, and in our mind's time, it was a process over time. } \\
\text { In other words, it should fade away by introducing either limited } \\
\text { franchise, or something like a tri-cameral parliament. We never } \\
\text { thought it would disappear overnight. So we became more and } \\
\text { more involved, and I started to get to know a number of individuals, } \\
\text { some of them who were under house arrest, but I also played quite a } \\
\text { role in bringing out a number of top Americans, particularly, some } \\
\text { Europeans, some Israelis, to the country incognito; some of them } \\
\text { did not want to come under their own names. Some of them would } \\
\text { not have a stamp in their passports; it was on a piece of paper. I } \\
\text { them to study every shade of political opinion, from the PAC, } \\
\text { ANC, through to the Progressives, to the Nationalists, to the } \\
\text { Conservatives, to the AWB, for a period of time. So they could see } \\
\text { what we were facing. }\end{array}$ \\
\hline \multirow[t]{3}{*}{$\begin{array}{l}\text { Political } \\
\text { influence }\end{array}$} & \multirow[t]{3}{*}{3} & 1 & $\begin{array}{l}\text { I was very friendly with Neil van Heerden, the Director General of } \\
\text { Foreign Affairs. We worked very closely together, and I worked } \\
\text { with our embassy in Washington, and Israel, and London, and so } \\
\text { on. I would return from meetings with them and advise FW de } \\
\text { Klerk and Pik Botha what the hard facts were, so that I had a better } \\
\text { voice. If I voiced it openly; they would not even want to see me. }\end{array}$ \\
\hline & & 2 & $\begin{array}{l}\text { The founder was a NAP and I came from an SAP family. When the } \\
\text { family business was founded, there was an act that prescribed that } \\
\text { you had to have different toilets for the different races. But at the } \\
\text { family store's head office he refused to have this and there were } \\
\text { only separate toilets for men and for women and not for the } \\
\text { different races. }\end{array}$ \\
\hline & & 3 & $\begin{array}{l}\text { Another of our mantras was our treatment of our black clientele. } \\
\text { The growth and success of our two family businesses were } \\
\text { predicated on the goodwill, service and relationships that we } \\
\text { developed with our black clientele, which, together with providing } \\
\text { them with the best quality and styles, is still the Holy Grail of the } \\
\text { business today. Nothing was too much trouble in order to satisfy } \\
\text { our customers and our reputation grew as a result of this. }\end{array}$ \\
\hline
\end{tabular}


Table 3 continued

\begin{tabular}{|c|c|c|c|}
\hline Code & 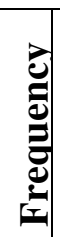 & $\ddot{\Xi}$ & Example \\
\hline BEE & 2 & 1 & $\begin{array}{l}\text { I have a very simple approach, you know, I think BEE is a "sine } \\
\text { qua non". It is imperative. We have to do it and we have to do it in } \\
\text { different ways, and I have found some quite innovative ways in } \\
\text { structuring it and funding it. In February 1991, when we were at the } \\
\text { World Economic Forum in Demas, De Klerk announced the release } \\
\text { of Nelson Mandela, and the unbanning of the ANC. We could } \\
\text { hardly believe this. None of us expected it. Nobody thought it was } \\
\text { going to happen, just like that. I then went to the President of the } \\
\text { World Forum and I asked him if the world will drop sanctions } \\
\text { against South Africa and how would he feel about it? A friend of } \\
\text { mine was with me, a former chief executive of Premier Milling. } \\
\text { This friend was very proactive in that scene. We both asked the } \\
\text { president, what if we could bring the past, the present and the future } \\
\text { of South African to the World Forum, De Klerk, Mandela and } \\
\text { Buthelezi? For the first time in history they would share the same } \\
\text { stage and would be able to tell the world the ultimate philosophy, } \\
\text { because we still had that interim situation, till 1994: the period of } \\
\text { Codesa. The world would begin to meet Mandela, not as a prisoner } \\
\text { and a murderer, and De Klerk as a human being who had done } \\
\text { amazing things to change, and Buthelezi who represented the } \\
\text { Zulus. }\end{array}$ \\
\hline \multirow[t]{2}{*}{ BEE } & 2 & 1 & $\begin{array}{l}\text { Well, he was ecstatic: "This is fantastic, because South Africa is } \\
\text { becoming more and more of a hot potato". One would not believe } \\
\text { the rebuffs that we as South Africans used to get, particularly from } \\
\text { the Far East and some of the other African countries. We were now } \\
\text { given prime time on CNN and other international news broadcasts, } \\
\text { and right after our session, for the first time the nine presidents of } \\
\text { the dismantling of the Soviet Union spoke together on the same } \\
\text { platform, of their proposals for those countries. Both made history } \\
\text { at that time and the whole world became aware of it: the fall of } \\
\text { apartheid and the fall of the communist union. Afterwards Mandela } \\
\text { said to me: "You know, you must understand that I have been } \\
\text { silenced for so many years, but here was my first opportunity to say } \\
\text { what I wanted to say to the world". }\end{array}$ \\
\hline & & 2 & $\begin{array}{l}\text { We developed a BEE company: which handled all our government } \\
\text { contracts and have a } 49 \% \text { interest in it. }\end{array}$ \\
\hline \multirow[t]{2}{*}{ Aids prevention } & \multirow[t]{2}{*}{2} & 1 & $\begin{array}{l}\text { We have trained } 5000 \text { kids playing in field bands in } 23 \text { different } \\
\text { locations in the country. They are also taught about Aids, and Aids } \\
\text { prevention. Some of them have become spokesmen on Aids } \\
\text { prevention. We undertook a recent survey amongst about } 40 \text { odd } \\
\text { percent of our kids, from } 14 \text { years up to } 18,19 \text {. There was less than } \\
\text { one percent prevalence of HIV. }\end{array}$ \\
\hline & & 2 & $\begin{array}{l}\text { As a strategic response to HIV/Aids, award winning workplace } \\
\text { programme successfully minimises the impact of the disease on the } \\
\text { company through a range of interventions, including providing anti- } \\
\text { retroviral treatment (ART) for employees and their spouse or life } \\
\text { partner. }\end{array}$ \\
\hline
\end{tabular}


Table 3 continued

\begin{tabular}{|c|c|c|c|}
\hline Code & 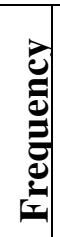 & 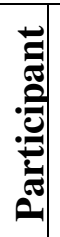 & Example \\
\hline \multirow[t]{2}{*}{$\begin{array}{l}\text { Helping people } \\
\text { to help } \\
\text { themselves }\end{array}$} & 2 & 1 & $\begin{array}{l}\text { Because of to Aids, it is estimated that by } 2010 \text { in South Africa, } \\
\text { around two million children will be left to fend for themselves in an } \\
\text { ominous new phenomenon called child-headed households. At best, } \\
\text { we are working at providing sufficient care so that the children of } \\
\text { South Africa can grow up with love, morals and the promise that an } \\
\text { education holds. }\end{array}$ \\
\hline & & 2 & $\begin{array}{l}\text { From a national perspective we have in the past been involved in } \\
\text { Habitat for Humanity. Essentially it is a fantastic programme that } \\
\text { looks to empower people to build their own homes. }\end{array}$ \\
\hline $\begin{array}{l}\text { Creation of self- } \\
\text { discipline in } \\
\text { underprivileged } \\
\text { children }\end{array}$ & 1 & 1 & 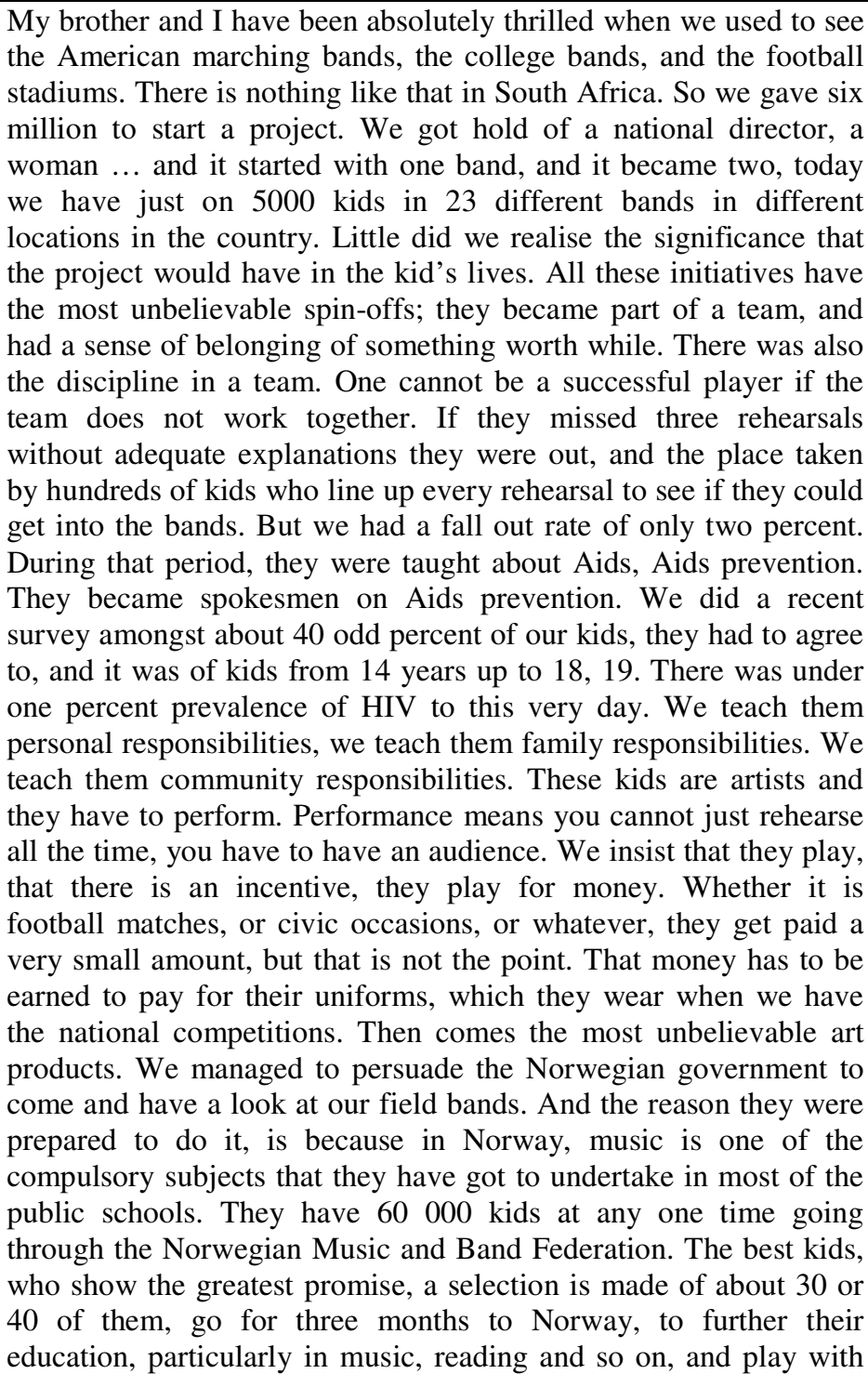 \\
\hline
\end{tabular}




\begin{tabular}{|l|l|l|l|}
\hline Medical support & 1 & 1 & $\begin{array}{l}\text { their top bands. Then about eight to ten every year go for nine } \\
\text { months to Norway, to further their education. }\end{array}$ \\
\hline $\begin{array}{l}\text { One day Zelda phoned and told me that Madiba wanted to speak to } \\
\text { me. He said: 'young man, you have got to do me a favour. On my } \\
\text { desk I've got a picture of a young girl who is going to die, if she } \\
\text { doesn't get medical treatment. Her muscle system, her nervous } \\
\text { system around her face is collapsing, her eyes are closing, and soon } \\
\text { she won't be able to swallow. So she either has to be fed } \\
\text { intravenously for the rest of her life, or receive specialised surgery. } \\
\text { There is only one surgeon that can cure her that they know of. He is } \\
\text { in Toronto Canada, and there are high costs and high risk involved. } \\
\text { So, I said to him, to leave it to me. My son phoned the surgeon, told } \\
\text { him that Mandela wanted him to come out. Would he do it free of } \\
\text { charge? He said: not only will I do it free of charge, I'll bring a } \\
\text { team from Johns Hopkins hospital, which is the biggest paediatric } \\
\text { hospital in the world. He brought a team out and helped to train } \\
\text { specialists in South Africa on this and other facial problems, } \\
\text { without any cost. The child subsequently recovered. Mandela was } \\
\text { over the moon. As a result of this, our family has set up 'The Smile } \\
\text { Foundation', with my son as chair person. Through these } \\
\text { circumstances hundreds of kids are being operated on in this } \\
\text { country. There is a special week, every few months, the hospital } \\
\text { gives us beds and free accommodation treatment, and the specialists } \\
\text { offer their services free. Now, Mandela's one concern, for one } \\
\text { child, has turned the lives of hundreds of kids ... Not just the } \\
\text { children, also the South African medical profession has got this } \\
\text { knowledge now. }\end{array}$ \\
\hline
\end{tabular}

\section{Figure 3: The role of "familiness" in the performance of social capital}

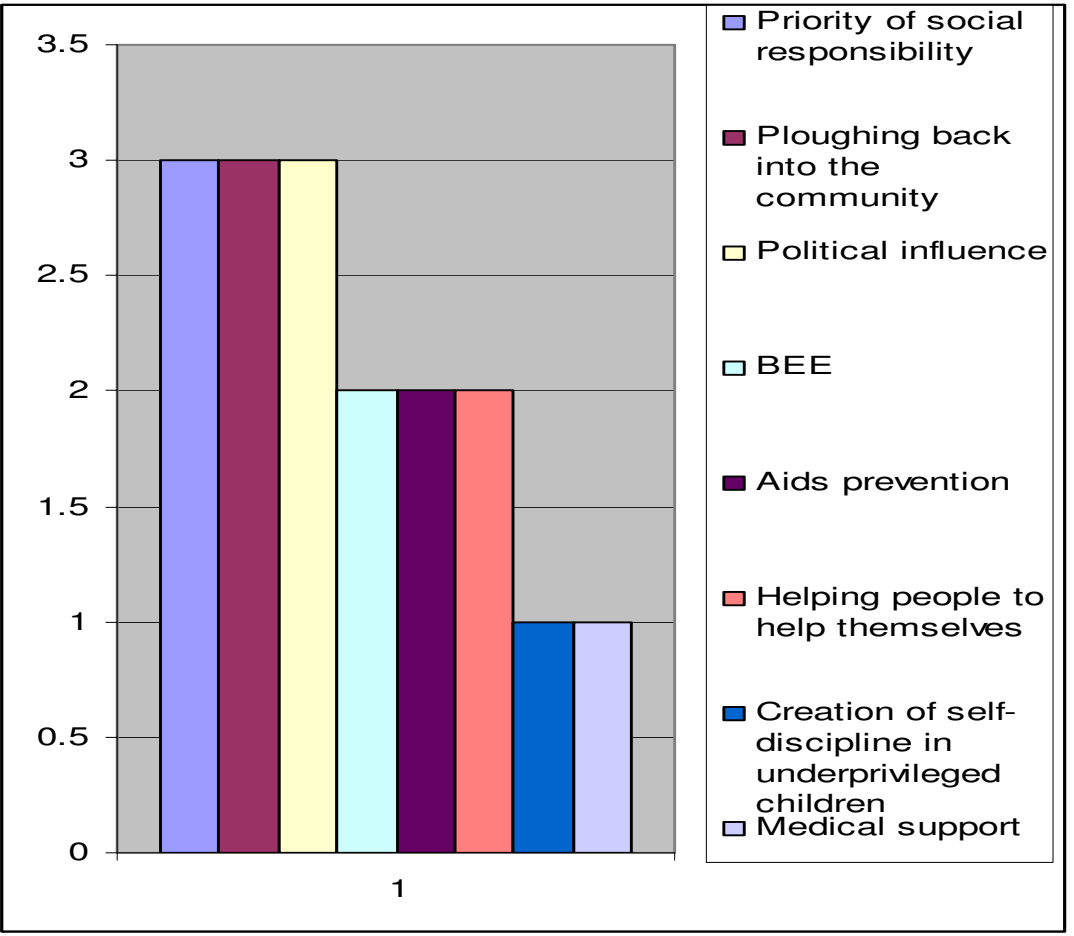


Social responsibility $(\mathrm{n}=3)$ seems to be a major priority in the social capital channel of family businesses, ploughing back into the community $(\mathrm{n}=3)$ while acknowledging the benefits and business opportunities the company receives from the community at large. Some of the South African family-business groups have exercised important political influence $(\mathrm{n}=3)$, especially during the apartheid years, by openly opposing the government of the day. It was felt that today's Black Economic Empowerment (BEE) $(n=2)$ requirements stemmed from these initiatives and culminated in legislation that has moved BEE a massive step forward. Monetary aid is provided for HIV/Aids research, as well as direct assistance for those already suffering from the condition, through the prevention of Aids $(\mathrm{n}=2)$ programmes. In the process, training is offered to HIV/Aids sufferers, which enables them to help themselves $(\mathrm{n}=2)$ and, as a result, plays a meaningful role in the economy. This tends to prove that family businesses have a "heart" and practise a caring influence in respect of this dreaded disease. On the other hand, the development of important upliftment projects for underprivileged children seems to play an important role in the creation of self-discipline in underprivileged children $(\mathrm{n}=1)$. The role that family businesses play in medical support $(\mathrm{n}=1)$ of the community should not be underestimated.

\section{Conditional matrix}

A conditional matrix was formed as suggested by Goulding (2002:87) andStrauss and Corbin $(1990: 11 ; 1998: 190)$, on the grounds of the following lines of reasoning:

- The numbers of the codes were grouped into categories that logically belonged together.

- The average of the code categories was calculated by dividing the total of the comments by the number of channels.

Table 4: Grouping of codes into logical categories

\begin{tabular}{|c|c|c|c|}
\hline Name of code & Category code & $\begin{array}{l}\text { Total } \\
\text { comments }\end{array}$ & Average \\
\hline $\begin{array}{l}\text { Instilling values } 3 \\
\text { Priority of social values } 3 \\
\text { Founder sets tone } 2 \\
\text { Example of parents } 2 \\
\text { Word of mouth } 1\end{array}$ & $\begin{array}{l}\text { Instilling social values in } \\
\text { family and business }\end{array}$ & 11 & 3.7 \\
\hline $\begin{array}{l}\text { Morale } 2 \\
\text { Appointment of underprivileged } 1 \\
\text { Providing for underprivileged } 1 \\
\text { Creating entrepreneurs } 2 \\
\text { Importance of providing jobs } 1\end{array}$ & $\begin{array}{l}\text { Creating a morale of high } \\
\text { social responsibility }\end{array}$ & 7 & 2.3 \\
\hline Philanthropy 5 & General philanthropy & 5 & 1.7 \\
\hline $\begin{array}{l}\text { Positive political influence } 3 \\
\text { BEE } 2\end{array}$ & Positive political influence & 5 & 1.7 \\
\hline $\begin{array}{l}\text { Ploughing back into society } 1 \\
\text { Ploughing back into community } 3\end{array}$ & Ploughing back into society & 4 & 1.3 \\
\hline $\begin{array}{l}\text { Aids prevention } 2 \\
\text { Medical support } 1\end{array}$ & Medical support & 3 & 1 \\
\hline $\begin{array}{l}\text { Helping people to help themselves } 2 \\
\text { Creation of self-discipline in children } 1\end{array}$ & Self-help/self-discipline & 3 & 1 \\
\hline
\end{tabular}

Figure 4 is an illustration of the conditional matrix of the investigated important social responsibility categories of the investigated sample of family businesses. 
Figure 4: Conditional matrix of social responsibility activities of investigated family businesses

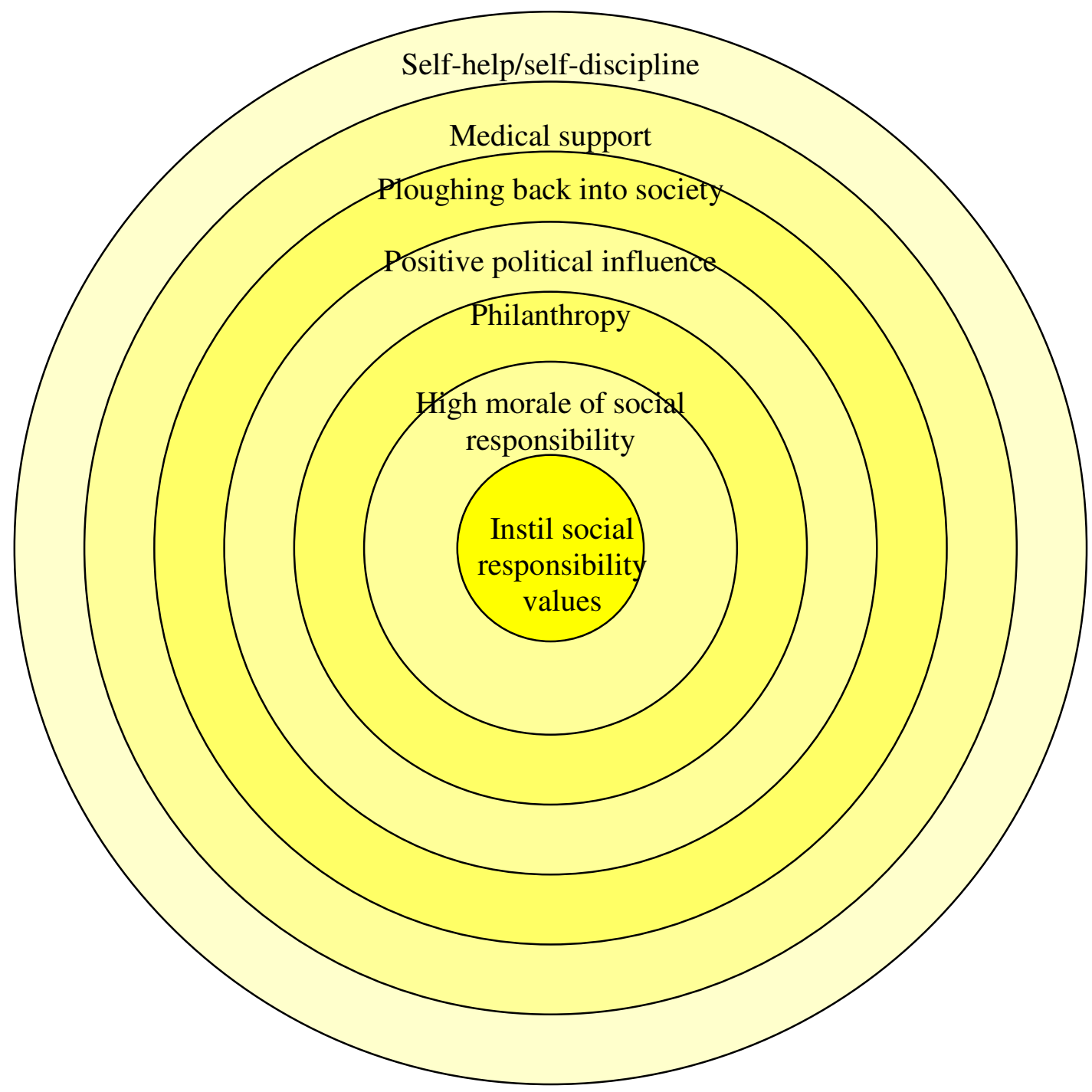

In respect of the investigated family businesses, Figure 4 indicates that instilling socialresponsibility values in the family and the business is the nucleus of social conscience in those businesses, giving the highest priority to ubuntu-driven actions. Sensitising family members and employees to a business ethos of social responsibility issues in the family businesses is nurtured by sustaining a positive morale in the resolution of community issues, leading to continuous philanthropic support, even to the extent of pursuing reconciliation as mediators in political affairs. In this way, family businesses continuously plough back, into the society which they embrace, value and respect as 
intangible pillars of the family business. Some of these family businesses have even been involved in medical, self-help and self-discipline programmes.

\section{Discussion}

It is concluded that the social capital culture of family businesses seems to be closely related to the concept of ubuntu. The findings indicate the intrinsic care of these family businesses, ploughing back benefits, and uplifting and providing dignity to the communities in which they function. Answers to the open-ended questions indicate that philanthropy and social responsibility issues enjoy high priority in these family businesses, which continuously plough back resources into the communities which they serve. This finding confirms the postulation that family businesses are highly orientated towards social responsibility (Lester \& Canella, 2006:755; Stavrou et al., 2007:157; Ward, 2003:72) and keenly involved in philanthropic care (Ward, 2003:128), fulfilling a valuable role in the values of communities (Kleberg, 2001:10).

Social capital activities are seen as a method of instilling the values of the family business whilst uplifting the morale of the business. This emphasises the argument of Aronoff et al., (1996:13) and Aronoff \& Ward (2001:31), that a strong sense of identity and empowerment is formed through family businesses' social responsibility activities. They create a sense of meaning in a family business (Ellis, 2002:63).

It seems that it is especially the founders of family businesses that set the tone in establishing social responsibility programmes. In this way, the community is served in many ways: entrepreneurial qualities are nurtured in society, underprivileged individuals are taken care of and uplifted, and BEE is actively practised. In supporting underprivileged individuals the businesses also teach them to help themselves by nurturing self-discipline and encouraging them, for example, to participate in the prevention of Aids through various educational programmes.

The important role family businesses have played and are playing behind the scenes in the dismantling of apartheid became evident during these interviews. They played a significant role in influencing the political climate of the country as a whole, not least in bringing opposing parties together for negotiation, a process that eventually led to the transition of power and the democratic election of the first multi-racial South African government (Aronoff \& Ward, 1995:122; Dommisse \& Esterhuyse, 2005:93; Gibson, 2002:128; Heck et al., 1994:3-4; Hocking, 1973:193, 197; Marx, 1986:217; Venter, 2003:10, 22; Wessels, 1988:212).

The main conclusion is that social responsibility programmes within family businesses give these businesses the opportunity to plough back into society many valuable resources in order to uplift those communities from whom the businesses receive most support. In this way, the businesses help to create a healthy society in which to operate.

According to Lester and Canella (2006:767), the literature concerning community-level family-business social capital activities is not extensive when compared with the 
literature relating to non-family businesses. In this regard, the current study makes an important contribution to the body of knowledge concerning family-business social capital activities.

\section{Limitations of the study}

Only a small portion of large family businesses in South Africa were investigated. It would be interesting to compare the findings of the current study with investigations of large family businesses in other countries, and with smaller family businesses in South Africa and other countries.

Some questions were sensitive in nature. It is possible that, because of the sensitivity of the subject-matter, answers relating to this issue might have been subject to response bias. Another factor is that, because the owners and founders of large family-business groups notoriously guard their privacy, there is a possibility that response bias could have affected the answers to some of the questions.

The time limitation imposed by the seniority of the interviewees made it difficult to discuss each question in the detail that it deserved. It has to be emphasised that because of the time limitation of some of the individuals interviewed, and the setting of nonprobing questions, coupled with their general unwillingness to report on social responsibility issues (probably due to their reluctance to boost their own egos), these family business owners probably under-represented the true role they play in the betterment of society.

\section{Directions of future research}

Future research could draw a comparison between the social capital activities of family businesses and those of non-family businesses.

Future studies could also include more structured forms of investigation, for instance, more structured interviews and Likert-type questionnaires that might provide a more quantitative investigation of the phenomenon of social capital activities.

\section{Conclusion}

The social-responsibility programmes within large family businesses give these businesses the opportunity to plough back into society some valuable resources and in so doing uplift those communities from whence such businesses receive their greatest support. In this way, the businesses help to create a relatively healthy society in which to do business. 
The implication is that social-responsibility programmes should be carefully nurtured in family businesses because of the important role they play in creating a stable and healthy socio-economic society.

The study gives evidence of social responsibility activities in family businesses in South Africa that closely relate to and support the concept of ubuntu. Adoption and establishment of these collectivistic ubuntu activities by the general business community in this country could contribute tremendously to the alleviation of poverty and unemployment and to the support of the ever-increasing number of Aids orphans. The practising of social capital in family businesses confirms Nussbaum's (2003:7) argument that ubuntu gives an emotional soul to a business.

\section{References}

About Donald Gordon. 2006. (10p), [Online] Available from: www.gibs.co.za/home.asp [Downloaded: 2006-05-08].

Altron Annual Report. 2006, February 28. Johannesburg: Allied Electronics Corporation.

Altron Code of Conduct. 2006. [Online] Available from: http://www.altron.co.za /accountability.asp .pdf [Accessed: 2006-01-04].

Anglo American. 2005. Report to society 2005: Anglo American: a climate of change. London: Anglo American.

Anton Rupert. 2006. Tukkie, 14(1):8-14.

Aronoff, C.E., Astrachan, J.H. \& Ward, J.L. (eds). 1996. Family Business Resourcebook II: a guide for families who own businesses and the professionals who serve them. Marietta, GA: Business Owner Resources.

Aronoff, C.E. \& Ward, J.L. 1995. Family-owned business: a thing of the past or a model of the future? Family Business Review, 8(2):121-130.

Aronoff, C.E. \& Ward, J.L. 1996. Chief's toughest job: teacher. In: Aronoff C.E., Astrachan, J.H. \& Ward, J.L. (eds) Family Business Resourcebook II: a guide for families who own businesses and the professionals who serve them. Marietta, GA: Business Owner Resources: 59-60.

Aronoff, C.E. \& Ward, J.L. 2001. Family business values: how to assure a legacy of continuity and success. (Family Business Leadership Series, Number 12). Marietta, GA: Family Enterprise Publishers.

Babbie, E. 2005. The basics of social research. $3^{\text {rd }}$ ed. London: Thomson Wadsworth.

Barringer, B.R., Jones, F.F. \& Neubaum, D.O. 2005. A quantitative content analysis of the characteristics of rapid-growth firms and their founders. Journal of Business Venturing, 20(5):663-687.

Barron, C. 2006. The benevolent tycoon. Sunday Times, January 22:15.

Baylis, T. 2006. About Trevor Baylis, the inventor of the wind-up technology. Innovative Technology. [Online] Available from: www.windupradio.com/trevor.html [Accessed: 2006-06-16].

Binedell, N. 2005. Case-study: the Watson Group: shaking up traditions of the family business. Business Day Management Review, April:6-7. 
Bornheim, S.P. 2000. The organisational form of family business. Dordrecht: University of St. Gallen.

Clockwork Radios. 2002. September 6. [Online] Available from: www.bbc.co.uk/dna/h2g2/pdf [Downloaded: 2006-06-16].

Cooper, D.R. \& Schindler, P.S. 2006. Business Research Methods, $9^{\text {th }}$ ed. London: McGraw-Hill.

Coulson, M. 2006. The founder of a great SA business dynasty passes on, but his legacy will extend far beyond the business world. Financial Mail, January 27:42.

Dahle, C. 1999. The Freeplay Group, based in Cape Town, South Africa, builds products that capture the imagination of the world - and that change the world. The Agenda - Social Justice, April, 23:166-174. [Online] Available from: www.fastcompany.com/online/23/socjust.html [Accessed: 2006-06-16].

Davis, P. 1983. Realizing the potential of the family business. Organisational Dynamics, 5(1):47-56.

De Beers. 2005. Seven things you need to know about 'Living up to diamonds'. Leadership in HIV AIDS, $7: 16-25$.

De Vos, A.S. 2005. Combined quantitative and qualitative approach. In: De Vos, A.S., Strydom, H., Fouché, C.B. \& Delport C.S.L. (eds) Research at grass roots. $3^{\text {rd }}$ ed. Pretoria: Van Schaik: 357-366.

De Vos, A.S., Strydom, H., Fouché, C.B. \& Delport, C.S.L. (eds). 2005. Research at grass roots . $3^{\text {rd }}$ ed. Pretoria: Van Schaik.

Dommisse, E. 2006. Anton Rupert: prins van handel. Rapport, January 23:17-18.

Dommisse, E. \& Esterhuyse, W. 2005. Anton Rupert: a biography. Cape Town: Tafelberg.

Doolan, J. 2005. Anton Rupert: “Conservation without money is conversation”. Leadership, 255:18-22.

Ellis, E. 2002. Tata steels itself for change. Fortune, April 29:61-67.

Formby, H. 2006. Steely resolve: SA's self-made tycoon presides over a company with a bigger sales turnover than De Beers. Financial Mail, September 1:24-27.

Gibson, K. 2002. A case for the family-owned conglomerate. The McKinsey Quarterly, 4:126-137.

Glaser, B. \& Strauss, A. 1976. The discovery of grounded theory: strategies for qualitative research. Chicago: Aldine.

Goulding, C. 2002. Grounded theory: a practical guide for management, business and market researchers. London: Sage.

Greef, M. 2005. Information collection: interviewing. In: De Vos, A.S., Strydom, H., Fouché, C.B. \& Delport, C.S.L. (eds). 2005. Research at grass roots. $3^{\text {rd }}$ ed. Pretoria: Van Schaik: 286-313.

Heck, R., Upton, N., Bellet, W., Dunn, B. \& Parady, P. 1994. Family business as a field of study. Working paper, International Family Business Program Association. Durham: University of New Hampshire. [Online] Available from: www.genusresources.com.pdf [Downloaded: 2003-01-12].

Henning, E., Van Rensburg, W. \& Smit, B. 2005 Finding your way in qualitative research. $3^{\text {rd }}$ ed. Pretoria: Van Schaik.

Herd, D. 2006. At home with the Wieses. Top Billing, March:50-55. 
Hocking, A. 1973. Oppenheimer and son. Cape Town: McGraw-Hill.

Jones, I.W., Nyland, C.M. \& Pollitt, M.G. 2001. How do multinationals build social capital? Evidence from South Africa. (ESRC Centre for Business Research, Working Paper no. 220). Cambridge: University of Cambridge.

Karakoulaki, H. 2002. Social capital vs family-capital: allies or opponents? Economic geography research group, working paper 02-11. Oxford: University of Oxford. [Online] Available from: www.geog.ox.ac.uk/research/wpapers.pdf [Downloaded: 2003-03-03].

Kerlinger, F.N. \& Lee, H.B. 2000. Foundations of behavioural research. $4^{\text {th }}$ ed. London: Harcourt.

Kleberg, S.S. 2001. Destroying myths and creating value in the family business. Second Annual Family Business Gathering. Stetson University, Deland, Florida. Unpublished manuscript, February 2-3:1-16.

Koenderman, T. 1982. Altech's Bill Venter: the driving force. Management, August:20-29.

LaSpada, S. 2006. The role of philanthropy. Paper presented at the Step's Third Symposium: Succession and The Family Enterprise, 5-6 April 2006.

Lester, R.H. \& Canella, A.A. 2006. Interorganizational familiness: How family firms use interlocking directorates to build community-level social capital. Entrepreneurship Theory and Practice, 30(6):755775 .

Lincoln, Y.S. \& Guba, E.G. 1985. Naturalistic Inquiry. London: Sage.

Lovell, P. 2006. Fleming family and partners. Paper presented at the Step's Third Symposium: Succession and The Family Enterprise, 5-6 April 2006.

Lubner, R. \& Lubner, B. 1997. Plate Glass and Shatterprufe Industries Limited. Johannesburg: PGSI.

Malhotra, N.K. 1996. Marketing research: an applied orientation. $2^{\text {nd }}$ ed. London: Prentice-Hall International.

Maqoko, Z. \& Dreyer, Y. 2007. Child-headed households because of the trauma surrounding HIV/AIDS. HTS, 63(2):717-731.

Martos, M.C.V. \& Torraleja, F.G. 2007. Is family business more socially responsible? The case of GRUPO CIM. Business and Society Review, 112(1):121-136.

Marx, S. (ed.). 1986. Dr Anton Rupert: pro munere grates. Lesings as ere-professor in die Departement Bedryfsekonomie. Pretoria: Universiteit van Pretoria.

Neuman, W.L. 2000. Social work research methods: qualitative and quantitative approaches. Boston: Allyn \& Bacon.

Nevill, G. 2004, July. Property of the month: July 2004 - The soul of Spier. Property Magazine. (4p), [Online] Available from: www.thepropertymag.com/article.asp? contentid=7500.pdf [Downloaded: 200605-04].

Ngoenha, S.E. 2006. Ubuntu: New model of global justice? Indiglinga - African Journal of Indigenous Knowledge systems, 5(2):125-134.

Nussbaum, B. 2003. Ubuntu and business, reflections and questions. World Business Academy, 17(3):1-16. 
Parr, M. 2006. Building great African companies. Succeed, November:26-27.

Poovan, N., Du Toit, M.K. \& Engelbrecht, A.S. 2006. The impact of the social values of Ubuntu on team effectiveness. Paper presented at the First International Conference on Value Based Leadership, Stellenbosch, 14-16 March:1-21.

Poutziouris, P.Z., Steier, L. \& Smyrnios, K.X. 2004. Guest editorial: a commentary on family business entrepreneurial developments. International Journal of Entrepreneurial Behaviour \& Research, 10(12):711.

Prichard, D. 2004. Hearing grasshoppers jump: the story of Raymond Ackerman as told to Denise Prichard. Cape Town: David Philip.

Prichard, D. 2005. The four legs of the table: Raymond Ackerman's simple, straight-forward formula for success as told to Denise Prichard. Cape Town: David Philip.

Rogerson, G. (ed.). 2003. Memos from the chairman. $4^{\text {th }}$ ed. Johannesburg: Altron.

Romain, K. 1989. Larger than life: Donald Gordon and the Liberty Life story. Johannesburg: Jonathan Ball.

Salgado, I. 2006. Third generation tricky for family firms. The Star Business Report, June 5:14.

Serwer, A. 2004. The Waltons: inside America's richest family. Fortune, November 15:42-63.

Sol Kerzner: back with a bang. 2004. (3p), [Online] Available from: http://www.safrica.info/doing_business/investment/kerzner-on\&only.pdf [Downloaded: 2006-06-15].

Stavrou, E., Kassinis, G. \& Filotheou, A. 2007. Downsizing and stakeholder orientation among the Fortune 500: does family ownership matter? Journal of Business Ethics, 72(2):149-162.

Strauss, A. \& Corbin, J. 1990. Basics of qualitative research: techniques and procedures for developing grounded theory. Berlin: Springer.

Strauss, A. \& Corbin, J. 1998. Basics of qualitative research: techniques and procedures for developing grounded theory. Thousand Oaks, Calif: Sage.

Toyota chairman Wessels dies. 2002. December 3. (2p), [Online] Available from: www.cartoday.com/content/news/singelpage.aspn?in=3691.pdf [Downloaded: 2006-06-21].

Uhlaner, L.M., Van Goor-Balk, H.J.M. \& Masurel, E. 2004. Family business and corporate social responsibility in a sample of Dutch firms. Journal of Small Business and Enterprise Development, 11(2):186-194.

University of Cape Town, 2006. Samson Rickard Stuttaford. (1p), [Online] Available from: www.175.uct.ac.za/creative/?f=2\&s=1.pdf [Downloaded: 2006-06-20].

Van Maanen, J. 1979. Reclaiming qualitative methods for organizational research. Administrative Science Quarterly, 24(4):520-526.

Van Wyk, S. 2003, October 28. Where hope springs eternal. Mail \& Guardianonline. (5p), [Online] Available from: www.mg.co.za/articledirect.aspx?area=mg.pdf [Downloaded: 2006-05-04]. 
Venter, E., Boshoff, C. \& Maas, G. 2003. The influence of relational factors on successful succession in family businesses: a comparative study of owner-managers and successors. South African Journal of Business Management, 34(4):1-13.

Venter, W.P. 1984, March 28. Address by Bill Venter, chairman of the panel for the In Search of Excellence Conference. Unpublished manuscript, 1-8.

Venter, W.P. 2003. The role of familiness in the performance of family-business groups. Unpublished MPhil thesis. Johannesburg: Rand Afrikaans University.

Venter, W.P. 2007. The role of familiness in the success and failure of family-business groups. Unpublished DPhil thesis. Johannesburg: University of Johannesburg.

Vision was in advance of the new SA. 2001, July 29. (2p), [Online] Available from: www.suntimes.co.za/2001/07/29/business/surveys/survey17.pdf [Downloaded: 2006-06-16].

Von Ahlefeldt, J. 1983. Profile: Dr Albert Wessels. Success story in two fields. The Star, June 9:8.

Ward, D. 2003, July 24. Telephonic interview with the author. Johannesburg. [Interview notes in possession of the author.]

Wessels, A. 1988. Farmboy to industrialist. Johannesburg: Perskor.

White, L. 2006. The Gates way. Fair Lady, April:45-49.

Wits University Donald Gordon Medical Centre (WDGMC). 2008. Wits University Donald Gordon Medical Centre (WDGMC). [Online] Available from: http://www.dgmc.co.za/html [Accessed: 2008-0229].

Wood, S. 2004. Building a family fortune. Richer Life, November:18-20. 